\title{
Maintenance of efficacy of canakinumab in SJIA at the individual patient level in a 12-week pooled dataset
}

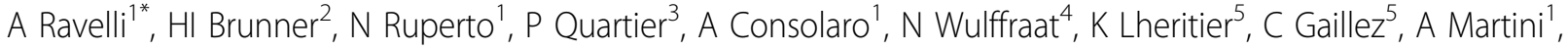 \\ DJ Lovell ${ }^{2}$
}

From 21st European Pediatric Rheumatology (PReS) Congress

Belgrade, Serbia. 17-21 September 2014

\section{Introduction}

Recent advances in the management of SJIA considered the induction or maintenance of inactive disease according to the JADAS 10-CRP (J10) or 27-CRP (J27) scoring system $[1,2]$. The maintenance of efficacy of canakinumab (CAN), a selective, human, anti-IL-1 $\beta$ monoclonal antibody, was demonstrated in the withdrawal phase of 2 phase III trials [3], but was not evaluated at the individual level.

\section{Objectives}

To evaluate the maintenance of efficacy at the level of the individual patient from Week 2 to 12, using the adapted ACR-JIA response criteria (aACR) as well as J10 and J27 on the 12-week pooled data set (3 phase III studies).

\section{Methods}

For this post-hoc analysis of the CAN Phase III program in SJIA, the change in disease states between Day(D) 15 and D85 of a total of 178 CAN-naïve patients was assessed. Subjects were 2-19 years of age and had active SJIA at enrollment. This shift analysis considered the aACR response and certain disease activity states as defined using J10 and J27: Inactive Disease (ID), Low Disease Activity (LDA), Moderate Disease Activity (MDA); High Disease Activity (HDA).

\section{Results}

J10 changes during the study period are provided in Table 1. Results for the J27 were very similar to the J10 observations.

${ }^{1}$ Instituto Gaslini-PRINTO, Genova, Italy

Full list of author information is available at the end of the article
Table $1 \mathrm{J10}$ shift analysis table from D15 to D85*

\begin{tabular}{cccccc}
\hline $\begin{array}{c}\mathbf{N} \\
(\%)\end{array}$ & $\begin{array}{c}\text { Disease State at Day } \\
\mathbf{1 5}^{*}\end{array}$ & \multicolumn{5}{c}{ Disease state at Day $\mathbf{8 5}^{*}$} \\
\cline { 3 - 6 } & & $\mathbf{I D}$ & LDA & MDA & HDA \\
\hline ID & $28(100)$ & 24 & $1(3.6)$ & $3(10.7)$ & $0(0.0)$ \\
& & $(85.7)$ & & & \\
\hline LDA & $20(100)$ & 10 & 10 & $0(0.0)$ & $0(0.0)$ \\
& & $(50.0)$ & $(50.0)$ & & \\
\hline MDA & $30(100)$ & $5(16.7)$ & 12 & 10 & $3(10.0)$ \\
& & & $(40.0)$ & $(33.3)$ & \\
\hline HDA & $44(100)$ & $2(4.5)$ & $6(13.6)$ & $8(18.2)$ & 28 \\
& & & & & $(63.6)$ \\
\hline
\end{tabular}

*Only patients with both a Day 15 and a Day 85 value are included

The D15-D85 aACR shift analyses, including only patients who had a D15 and a D85 value, likewise indicated that the majority of patients maintained or improved their response: NR $(n=32): 12.5 \%$ of patients improved; aACR30 ( $\mathrm{n}=14): 0.0 \%$ were maintained/ $78.6 \%$ improved; aACR50 ( $\mathrm{n}=21): 33.3 \%$ were maintained/42.9\% improved; aACR70 $(\mathrm{n}=36): 25.0 \%$ were maintained $/ 58.3 \%$ improved; aACR90 $(n=26): 30.8 \%$ were maintained $/ 57.7 \%$ improved; aACR100 $(n=34)$ : $82.4 \%$ were maintained.

\section{Conclusion}

The great majority of CAN patients either maintained or improved their JADAS status or aACR response level from week 2 to 12 . These data confirm the consistent maintenance of efficacy of CAN at the individual level in the first 3 months, irrespective of the measure of response, i.e. aACR criteria or JADAS-derived criteria, and extend previous findings at the study group level. 


\section{Disclosure of interest}

A. Ravelli Grant / Research Support from: Pfizer, Consultant for: Abbvie, Bristol Myers Squibb, Novartis, Pfizer, Roche and Johnson \& Johnson, Speaker Bureau of: Abbvie, Bristol Myers Squibb, Novartis, Pfizer, Roche and Johnson \& Johnson, H. Brunner Consultant for: Novartis, Genentech, Pfizer, UCB, AstraZeneca, Biogen, Boehringer-Ingelheim, Regeneron, Paid Instructor for: Novartis, Speaker Bureau of: Novartis, Genentech, N. Ruperto Grant / Research Support from: To Gaslini Hospital: Abbott, Astrazeneca, BMS, Centocor Research \& Development, Eli Lilly and Company, "Francesco Angelini", Glaxo Smith \& Kline, Italfarmaco, Novartis, Pfizer Inc., Roche, Sanofi Aventis, Schwarz Biosciences GmbH, Xoma, Wyeth Pharmaceuticals Inc., , Speaker Bureau of: Astrazeneca, Bristol Myers and Squibb, Janssen Biologics B.V.,Roche, Wyeth/Pfizer, P. Quartier Grant/Research Support from: Abbvie, BMS, ChugaiRoche, Novartis, Pfizer, SOBI, Consultant for: Abbvie, Chugai-Roche, Novartis, Pfizer, Servier and SOBI, Speaker Bureau of: Chugai-Roche, MEDIMMUNE, Novartis, Pfizer, A. Consolaro Consultant for: Novartis, N. Wulffraat Grant / Research Support from: Abbvie, Roche, Consultant for: Novartis, Pfizer, Roche, K. Lheritier Shareholder of: Novartis, Employee of: Novartis, C. Gaillez Shareholder of: Novartis, Employee of: Novartis, A. Martini Grant / Research Support from: The Gaslini Hospital, which is the public Hospital where I work as full time employee, has received contributions to support the PRINTO research activities from the following companies: Bristol Myers and Squibb, Centocor Research \& Development, GlaxoSmith \& Kline,Novartis,Pfizer Inc, Roche, Sanofi Aventis, Schwarz Biosciences $\mathrm{GmbH}$, Speaker Bureau of: Abbott, Bristol MyersSquibb, Astellas, Behringer, Italfarmaco, MedImmune, Novartis, NovoNordisk, Pfizer, Sanofi, Roche, Servier, D. Lovell Grant / Research Support from: National Institutes of Health- NIAMS, Consultant for: Astra-Zeneca, Centocor, Amgen, Bristol Meyers Squibb, Abbott, Pfizer, Regeneron, Roche, Novartis, UBC, Forest Research Institute, Horizon, Johnson \& Johnson , Speaker Bureau of: Novartis, Roche.

\footnotetext{
Authors' details ${ }^{5}$ Novartis Pharma AG, Basel, Switzerland.

Published: 17 September 2014

References

1. Consolaro, et al: Arthritis Rheum 2009, 61(5)

2. Nordal, et al: Ann Rheum Dis 2012, 71(7).
}

${ }^{1}$ Instituto Gaslini-PRINTO, Genova, Italy. ${ }^{2}$ PRCSG, Cincinnati, USA. ${ }^{3}$ NeckerEnfant Malades Hospital, Paris, France. ${ }^{4}$ UMC Utrecht, Utrecht, Netherlands.
doi:10.1186/1546-0096-12-S1-P69

Cite this article as: Ravelli et al:: Maintenance of efficacy of

canakinumab in SJIA at the individual patient level in a 12-week pooled dataset. Pediatric Rheumatology 2014 12(Suppl 1):P69.
Submit your next manuscript to BioMed Central and take full advantage of:

- Convenient online submission

- Thorough peer review

- No space constraints or color figure charges

- Immediate publication on acceptance

- Inclusion in PubMed, CAS, Scopus and Google Scholar

- Research which is freely available for redistribution

Submit your manuscript at www.biomedcentral.com/submit 